\title{
Austrian fraud trial adjourned
}

EARLY this month, the trial of Herbert Schaden, charged with fraudulently obtaining funds for research from a Dutch packaging firm, began in Vienna. But the case may never be settled in court. On the third day, an exhausted Schaden collapsed after 14 months in detention.

The trial continued after Schaden's collapse, until Hertha Celta, accused of having assisted him in the fraud, broke down when the prosecutor showed that some passages from the reports of their work had been copied from someone else's publications without acknowledgement. Celta told the court that she had simply typed what Schaden had given her. However, the court had already decided to halt the case until doctors ruled on whether Schaden was fit enough for further court appearances.

In 1973 Schaden claimed to be on the point of developing a strain of microbe which would digest plastic, but after four years no such strain was developed. From the beginning the case has involved bitter rows between the Austrian Ministry of Science and Research and some science journalists.

The indictment against Schaden cites articles from two Austrian papers and argues that some journalists wrote what Schaden and Celta had told them "apparently without checking its validity". The ministry has repeatedly accused the journalists concerned of being responsible for the loss of research funds worth six million schillings (about $£ 200,000$ ) by the Royal Packaging Industries van Leer B.V. of Amsterdam and 400,000 schillings $(£ 14,000)$ already paid by an Austrian businessman who was willing to invest $34 \mathrm{~m}$ schillings in Schaden's inventions. The court adjourned before the 'case of the science journalists'-as the Austrian research minister Dr Hertha Firnberg has dubbed it-could be taken up.

It is clear, however, that van Leer and Dr Roderich Weil, his scientific consultant, got in touch with Schaden because of a Dutch news report based on the Austrian articles. Van Leer said in court that Schaden told him his basic research had been done within the 'International Research Society for Geomicrobiology and Soil Hygiene'. (It was later shown that this is not an international society). Schaden offered him a research programme ready to be scaled up for industrial use. The van Leer group was interested and money started to flow to Vienna.

Van Leer said funds were sent solely on the grounds of what Schaden had told them in Vienna and because the international society and the names of the people involved in it seemed respect-

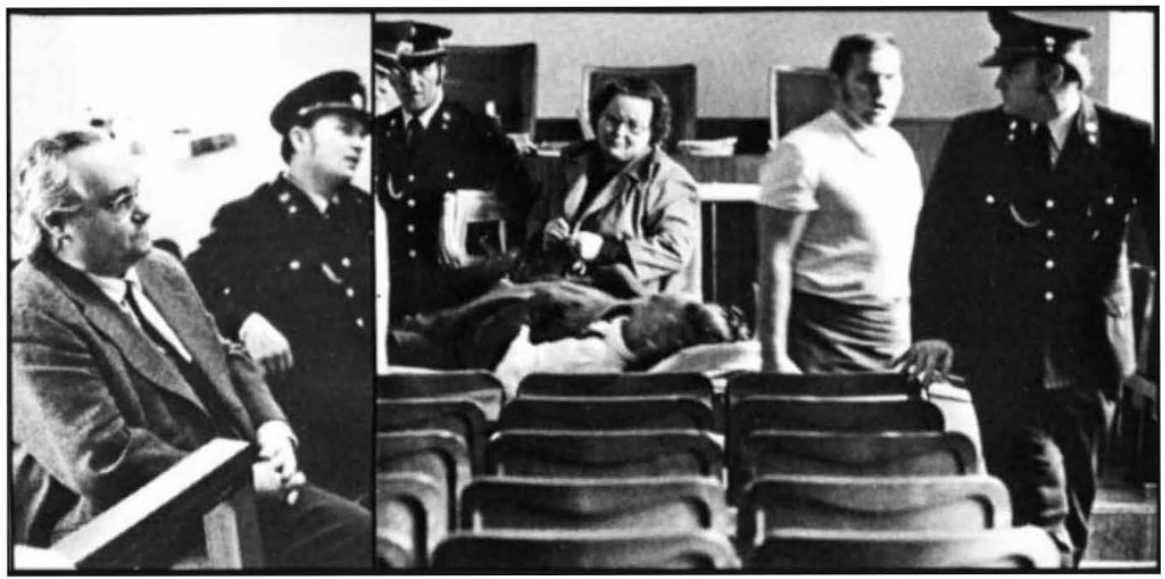

Schaden on trial (left) and being wheeled from the court room after collapsing

able. Nobody from the van Leer group ever saw the bacteria which Schaden claimed would end plastics refuse problems; nobody ever entered the sterile room in Schaden's laboratory; no specialist in microbiology was sent to investigate Schaden's work before the payments started.

However, van Leer did fly a team of scientists from Israel to Vienna to examine another of Schaden's claimsthat he could produce vegetation in deserts by 'bacteriaisation' of the ground. Even though the scientists had a poor opinion of Schaden the money continued in the hope of developing 'plastic-eating' microbes. Funds were only stopped when accounts of how the money had been spent began to arrive late from Vienna and reports of Schaden's work were infrequent and of poor quality.

One piece of evidence which van Leer and some of the journalists saw giving support to Schaden's credibility still remains a puzzle. Dr Heinz Dombrowsky from the University of Freiburg. West Germany, had made a written statement about the high quality of the work done in Schaden's laboratory. Van Leer said in court that Dombrowsky had been invited to Amsterdam when doubts about Schaden started to grow and that he had then been negative about Schaden. But, giving evidence in the Viennese trail, Dombrowsky stood by his earlier opinion of Schaden's ability in microbiology. (Schaden does not have a university degree). Dombrowsky did, however, make the reservation that he knew nothing of Schaden's work on 'plastic-eaters' since his contact with Vienna was over by 1973.

What of the other issues surrounding this case? There is the report written by the science journalist Peter Muller on behalf of the ministry (see Nature,
24 November, page 292) which according to the minister was compiled in the hope of preventing any future international ridicule of Austrian science. It was sent to members of parliament and universities and resulted in a heated discussion in parliament. Conservative MPs argued that the 32-page report, financed by the taxpayer, put undue pressure on journalists. They pointed to the assumption in the report that Schaden was guilty in spite of the fact that the court case had not been decided; a point which the minister replied to by saying that everything had already been clearly proved. A Liberal questioned the whole role of the ministry in the affair: if as early as 1973 and certainly as Muller says by 1974 the Ministry thought that Schaden was not to be trusted scientifically, why did it not warn the journalists who continued to write of Schaden's inventions?

These daily skirmishes in parliament partly reflect the stance taken by the opposing parties to the science policy of the ruling social democrats. But there have been some other unusual occurrences so far as science writers are concerned in the Schaden affair.

One of the incidents is particularly unpleasant. A story is spreading that one of the journalists had been paid by Schaden for the articles. A high official of the Ministry for Science and Research repeated the same story during a recent telephone conversation. The facts are that Dr Eleonore ThunHohenstein was asked to write a biography of Schaden several months after the first crucial articles had appeared in the Wochenpresse in early 1973. She received one payment but backed out of the business because she found Schaden too difficult to work with.

Edith Darnhofer 